This is a reviewed article

\title{
Explaining the appeal of militant Salafism in a Norwegian context
}

Ida Nord Holmer

inholmer@gmail.com

\author{
Keywords: \\ radicalisation \\ militant Salafism \\ jihad \\ Muslims \\ Norway
}




\begin{abstract}
By drawing upon existing literature on Islamic radicalisation, this article empirically explores why some Norwegian Muslims come to accept the use of violence in the name of Islam. Based on primary internet research and interviews with individuals who either call for violent jihad, or who have travelled to Syria to engage in armed struggle, this study identifies several complaints and grievances which may result in individuals adopting extreme positions. These grievances relate to Norwegian and Western foreign policies, feelings of being alienated and stigmatised in the public debate, a sense of not belonging, actual or perceived discrimination, and socio-economic deprivation. Interestingly, the findings in this study suggest that these factors are not significantly different in Norway than in other European countries facing the general trend of Islamic radicalisation. Rather, the ideological positions and statements identified in the data collection reflect the broader literature on the radicalisation of young Muslims living in Europe. In line with theories of Wiktorowicz (2005) and Roy (2004), this article therefore argues that Norwegian Muslims may become attracted to militant Salafism because it responds to their individual grievances, and provides an alternative worldview that offers meaning, community and justice based on shared religion and ideology.
\end{abstract}




\section{Introduction}

"Today, they humiliate our Islam, our Quran. They insult our Prophet, they invade Muslim lands, they massacre Muslims, and they wonder why we react, why we become terrorists? We will never, never give in and let ourselves be defeated. We are the ummah of Mohammad!"

Ubaydullah Hussain, $2012^{1}$

One day in September 2012, a group of about 100 individuals is gathered in front of the American embassy in Oslo. They have come together to protest against the controversial anti-Islamic movie Innocence of Muslims. Holding black Islamic flags, they shout Arabic slogans and honour Osama bin Laden as a freedom fighter: "Obama, Obama, we all are Osama!" The group is composed of both immigrants and those born in Norway (Akerhaug 2013; Lia, 2013). All were either raised as Muslims or converted to Islam later in life. They consider democracy to be a corrupt system, and believe that their interpretation of the Sharia system is the only legitimate law that should apply on Earth. Violent jihad in defence of Islam is seen as a duty to God, and throughout recent years they have openly encouraged Norwegian Muslims to travel to Syria and other conflict zones to participate in the "jihadist struggle".

The presence of likeminded individuals and groups that call for violence in the name of Islam, has recently drawn attention to the issue of Islamic radicalisation in Norway. Despite Norway's extensive welfare programs and efforts to integrate immigrants, extreme Islamism is considered the greatest threat to national security in Norway (PST, 2014; PST, 2015; PST, 2016). The fact that a remarkably high number of Norwegian citizens have travelled to Syria to take part in the conflict has also been at the centre of public attention. As of February 2016, the Norwegian Police Security Service (PST) estimated that at least 80 individuals had left the country to fight alongside militant groups in Syria and Iraq. The PST has previously emphasized that the actual number might be higher due to unreliable statistics (Dagens Næringsliv, 2015; PST, 2015). Adjusting for population size, Norway, along with Sweden, Denmark and Belgium, had one of the largest contingents of Muslim foreign fighters in Syria compared to other countries in Europe in 2013 (Hegghammer, 2013a).

Accordingly, the starting point for this article is to try to understand the following puzzles: Why do some individuals - who may perhaps have been born and raised in Norway - seek out distant conflicts, and take up arms in the name of Islam? Why do some individuals, who are apparently well-integrated, come to adopt beliefs that are anti-Western, antidemocratic, and essentially violent?

Based on a combination of primary sources, including internet research and interviews with Norwegian Muslims who either call for violent jihad, or who have travelled to Syria to participate in armed struggle, this article explores why some individuals turn to ideologies that promote violence. Accordingly, the next few pages are devoted to exploring the following research question: "Why do some Norwegian Muslims become attracted to militant Salafism?"

The first step towards answering this question is to examine what background contributing factors are liable to trigger a radicalisation process. Based on a study of individual motivations and justifications, I have identified a number of grievances that may explain

1 Ubaydullah Hussain, the spokesman for Profetens Ummah, was holding a speech to the crowd (Profetens Ummah, 2012). 
why some Norwegian Muslims come to accept the use of violence in the name of Islam. I found that the informants in this study did not feel themselves to be an integral part of Norwegian society. Some felt alienated, excluded and not fully accepted as Norwegians. Clearly they felt that the Norwegian authorities, and Norwegian society as a whole, subjected them to a double standard on account of their Muslim identity. Other individuals found themselves in a vicious cycle of lack of opportunity, unemployment and crime. Finally, the majority of the informants expressed anger and frustration about Norwegian foreign policies towards the Middle East, which strengthened their feelings that Norway, along with its Western allies, is waging a military and ideological campaign against Muslims.

Interestingly, the findings in this study suggest that these factors are not significantly different in Norway than in other European countries facing the general trend of Islamic radicalisation. Rather, the ideological positions and statements identified in the data collection reflect the broader literature on the radicalisation of young Muslims living in Europe (see for example Slootman and Tillie, 2006; Ranstorp, 2010; Wiktorowicz, 2005). In line with the theories of Oliver Roy (2004) and Quintan Wiktorowicz (2005), this article therefore argues that the appeal of militant Salafist ideology among some Norwegian Muslims may be prompted by real or perceived experiences of injustice. When analysing the individual statements and claims, I observed that all the informants shared feelings of strong resentment or injustice at having been unfairly treated in some way. Individuals may turn to militant Salafist ideology because it articulates their individual frustrations and grievances, and provides an alternative worldview that offers justice, meaning and community based on a shared religion and ideology.

\section{Defining radicalisation and militant Salafism}

The term "radicalisation" has often been a source of contestation and confusion because it has no established definition (Githens-Mazer and Lambert, 2010; Hegghammer, 2013b; Neumann and Rogers, 2007). Taking this into consideration, it is important to state clearly how the concept is understood by the author of this article. When referring to radicalisation, I mean the "...change in beliefs, feelings, and behaviours in directions that increasingly justify intergroup violence and demand sacrifice in defence of the in-group" (McCauley and Moskalenko, 2008: 416). Hence, this article focuses specifically on violent radicalisation - a process in which radical ideas are developed to the point where individuals either come to accept the use of, or engage in, violent acts (Dalgaard-Nielsen, 2010).

Moreover, radicalisation processes may occur in relation to a number of different ideologies and political orientations. This article focuses on radicalisation as it relates to militant Salafism, i.e., a religiously inspired type of radicalisation. The starting point when addressing the research question is therefore to identify the content of this ideology. In order to understand why some Norwegian Muslims come to accept violent beliefs, one has to understand the very ideology we are dealing with.

Essentially, there are two main dimensions to militant Salafist ideology, one religious and one political (Egerton, 2011). The religious dimension entails an orthodox or Salafist interpretation of Islam, requiring followers of the ideology to return to what they believe is the purest and most authentic version of Islam. ${ }^{2}$ Within militant Salafist ideology, religious literacy is combined with a political perception that Islam is under attack. Militant Salafists

2 Salaf is an Arabic word meaning "early generation" or "predecessor". It should be noted that someone who is a Salafist is not necessarily radical, nor will this person automatically become radicalised. Generally, one can distinguish between apolitical Salafists, political Salafists, and militant Salafists. Contrary to apolitical and political Salafists, militant Salafists advocate violent means. See for example Slootman and Tillie (2006) for an in-depth analysis of the nuances within the Salafi movement. 
perceive a global conflict between Islam and the West, one in which they feel obliged to participate (Egerton, 2011; Roy, 2008; Sageman, 2004). Based on a particular reading of the Islamic texts, militant Salafists claim that there is a religious obligation to act with force against the enemies of Islam, and that this obligation means that they are living, killing and dying in accordance with the teachings of Islam. The political idea of a global conflict between Islam and the West is illustrated by a comment made by a Norwegian Muslim who has been fighting in Syria. In a video posted online he paints a picture of the West constantly attacking Islam:

As for myself, I am born in the West, I am a Norwegian citizen, and I have spent 20 years of my life in the West. Through this time I have learned that you infidels consider Islam as your greatest enemy and a threat to your wicked, materialistic and cursed society and civilisation (Mohyeldeen Mohammad, 2012).

Among militant Salafists, violent jihad in defence of Islam is seen as a duty to Allah, with inspiration and motivation being found in Islamic texts (Egerton, 2011). ${ }^{3}$ A majority of my interviewees justified the duty of jihad in religious terms, as illustrated by this comment:

It is compulsory for every Muslim to support jihad. The Prophet Muhammad, peace be upon him, said that a Muslim who dies without the intention of carrying out jihad, dies in a state of hypocrisy. Therefore, every Muslim is obliged to support jihad, whether it is militarily; whether it is verbal - by speaking against those who supress Muslims; or economically - through welfare, strategy, and so on. (Interview with Ubaydullah Hussain, spokesman for Profetens Ummah, 15.7.14)

The appeal of militant Salafism among young Muslims is a phenomenon that is far from confined to Norway. Rather, it is a general trend across Europe. Muslim communities in various European countries have been affected to some extent by the influence of radical Salafist movements (Emerson, 2009). Incidents involving Islamist plots and terrorist attacks in several European countries illustrate that Europe is facing a new threat of so-called "homegrown" terrorism (Coolsaet, 2011). ${ }^{4}$ This has called attention to the issue of Islamic radicalisation in the West.

Nevertheless, it is important to acknowledge the variations and nuances that exist within militant Salafist ideology. In the literature on radicalisation, it is too often assumed that the radicalisation process ultimately results in terrorist acts. As Thomas Hegghammer (2013b) points out, few scholars have made an analytical distinction between the different types of violent activism. Among militant Salafists there may be differences regarding when and how militant jihad should be applied. Although some individuals may support Muslim insurgencies in Muslim countries, this does not necessarily mean that they support attacks in the West (Hegghammer, 2013). This point is illustrated by a British radical interviewed by Neumann and Rogers (2007: 79):

3 The concept of jihad ("to strive") is often misunderstood because it has various meanings. To most Muslims it refers to the inner struggle to become a good and devout Muslim. In relation to militant Salafism, it often refers to an armed struggle against the enemies of Islam. This latter interpretation is based on a broad and aggressive interpretation of self-defence (Egerton, 2011).

4 The Madrid train bombing in 2004, the London underground bombing in 2005, and the murder of Theo Van Gogh in Amsterdam in 2004, are all examples of homegrown terrorism (see for example Emerson 2009). 
I understand the acts of resistance in Afghanistan. They are freedom fighters. They don't go to the United States to carry out acts of terrorism. I sympathise with the people who fight in Afghanistan, in Iraq, in Palestine, in Sudan. I don't agree with the ones who commit acts in an underground, a train, a plane.

Having defined some key concepts, the next few pages of this article will briefly outline some of the existing literature on radicalisation in order to establish the theoretical framework of this study. I will then proceed to my main findings, before presenting an analysis of these findings.

\section{An insight into the study of radicalisation}

Understanding the processes of radicalisation is a highly complex task. Generally, there is no single cause or mechanism leading to radicalisation (Ranstorp, 2010). On the one hand, radicalisation processes are highly individual, with the speed of progression and the degree of devotion differing from person to person. What is more, research on radicalisation in Europe tells us that there is no unique or mainstream profile of radicals. They may be welleducated and employed, or they may come from socio-economically deprived families (Nesser, 2010). On the other hand, radicalisation is very context-dependent. It does not occur in a vacuum, but rather in relation and in response to a person's surroundings, for example, their political, economic and social context (Taylor and Horgan, 2006). Due to the complex nature of radicalisation processes, much has been said and written on the topic. Today, scholars are still discussing why some Muslims living in the West become attracted to violent interpretations of Islam.

A growing body of literature focuses on the social mechanisms of recruitment and mobilisation. Marc Sageman's (2004) ground-breaking work suggests that people join terrorist groups mainly on the basis of close bonds of family and friendship. Although Sageman focuses on recruitment to terrorist cells, his work can definitely tell us something general about the social mechanisms of radicalisation and recruitment. He was one of the first to argue that an understanding of social relationships and group dynamics should lie at the centre of the analysis. In his study of a radical Islamist group in London, Quintan Wiktorowicz (2005) uses social movement theory to explain how individuals are drawn to radical groups. He maintains that radicalisation is a social process that occurs within a group through social interaction. Other studies on recruitment and mobilisation concentrate on the role of the internet as a catalyst for the radicalisation process, highlighting its function as a source of recruitment and indoctrination (Maher, 2007; Musawi, 2010; Sageman, 2008). Websites, discussion forums and chat rooms play an increasing role in shaping specific political and religious perceptions among potential recruits. Generally, explanations concentrating on social mechanisms of mobilisation and recruitment are useful because they say something about how radical beliefs become channelled into action.

Another major body of literature focuses on the background contributing factors, or root causes, of the radicalisation process. Suggested causes range from the stigmatisation and polarisation of Muslim communities in the public debate, local government policies, unemployment, a lack of opportunities, influential leaders and imams, and political discourse (see for example Korteweg et al., 2010; Coolsaet, 2011). Many scholars refer to the role of Western foreign policies as a source of radicalisation (ibid.). Yet, only a limited number of studies offer a comprehensive analysis of the relationship between foreign policies and radicalisation at home. Arun Kundnani (2014) argues that in order to understand why Muslims in the West turn to violent interpretations of Islam, one must realise that Western states, with their rhetoric about conducting a "war against terror", have 
contributed to the political imagery of the West as being at war with Islam. Other scholars have offered socio-psychological explanations in the attempt to explain why individuals become radicalised. The French sociologist Oliver Roy (2004) maintains that the move towards militant Salafism in the West is an attempt to reconstruct a lost identity and a feeling of community in what is perceived as a hostile West. Experiences of discrimination and exclusion in Europe contribute to a situation where individuals feel detached from society. Militant Salafism offers solutions to these grievances by providing an alternative community based on a shared ideology and religion. The strength of Roy's theory is that it offers an explanation why militant Salafism appeals to individuals who come from well-off backgrounds or are apparently well-integrated. Yet, structural explanations have been criticised for failing to provide an adequate explanation for why only a minority of the population ultimately becomes radicalised. Nevertheless, a root-cause-based approach may definitely give us some insights into the "conditions that produce and provide the fertile ground in which extremism and violence can grow and take root" (Bjørgo, 2005: 1).

As we have seen, some scholars focus merely on the sources of radicalisation, whereas others concentrate on how radical ideas are transmitted through social networks. One of the problems with the radicalisation discourse, however, is that these explanations are too often presented as competing theories. In contrast, I argue that rather than being mutually exclusive, these theories reinforce each other. The different explanations reflect different levels of analysis and therefore offer different insights into the topic.

In order to understand the appeal of militant Salafism among Norwegian Muslims, I believe the first step is to gain an insight into the individuals' own motivations and of their understanding of the context they are embedded in. Accordingly, I find it most appropriate to adopt a root-cause-based approach with a particular focus on individual motivations and justifications for either supporting or taking part in religious violence. I will concentrate on what I believe is the most important contribution to this literature: Oliver Roy's Globalised Islam (2004). For a further insight into the socio-psychological process of radicalisation and how individuals come to conceptualise themselves as a collective, I will consider Quintan Wiktorowicz' Radical Islam Rising (2005).

\section{The search for meaning, community and justice}

According to Oliver Roy (2004), actual or perceived stigmatisation and alienation of Muslim communities in Europe contribute to an atmosphere where young Muslims feel detached from society and where their sense of belonging is lost. These feelings of exclusion at home are woven together with the suffering of Muslims in other parts of the world, feeding into the picture of a hostile West. As a result, some individuals develop a strong need for justice. As the objective of militant Salafists is to fight back at what they perceive as an aggressive West, militant Salafism somehow offers a "just cause" where dignity and pride can be retrieved. Secondly, as a solution to feelings of not belonging, militant Salafism may provide a sense of community based on collective solidarity and affiliation with the Islamic ummah the global community of Muslims. ${ }^{5}$ Finally, militant Salafism offers a sense of meaning. It is composed of a fixed value system with clear norms establishing what is and what is not permissible. Accordingly, militant Salafism can offer both meaning and stability, precisely what many young individuals need.

5 Ummah (derived from the word umm, meaning mother) is the Arabic word for community. It refers to the global community of believers (Egerton 2011: 4). 


\section{Cognitive openings}

Quintan Wiktorowicz's (2005) work has been acknowledged primarily for its insights into the radicalisation process within groups. Nevertheless, Wiktorowicz also offers an excellent analysis of the "pre-radicalisation" process in individuals. In line with Roy (2004), Wiktorowicz argues that the radicalisation process is usually triggered when an individual experiences some sort of crisis. The crisis may relate to social, political, or economic factors. For example, the individual may have experienced humiliation, racism, unemployment, lack of social mobility, or political discrimination. Whether the situation is real or perceived, the individual is likely to experience strong feelings of resentment or injustice. Subsequently, these feelings may provoke what Wiktorowicz calls a "cognitive opening". This is a state of mind where the individual starts questioning previously held beliefs and become more receptive to new beliefs and ideas. Wiktorowicz argues that the individual may become attracted to radical Islamic movements because they offer explanations for the individual's concerns and frustrations. Moreover, the alternative worldview advocated by such movements offers a set of values and something for the individual to identify with, often purportedly derived from a community of the most authentic or "true" believers. Through this analysis, Wiktorowicz hypothesises a social production of meaning, as individuals come to identify and conceptualise themselves as a collective.

\section{Notes on methodology}

\section{Research design}

My analysis is based on a combination of primary sources, including internet research and interviews. The latter included e-mail interviews, phone interviews and in-person semistructured interviews, conducted in June and July 2014.

To balance the analysis and broaden my view, the interviews are supplemented with data from open sources, such as articles in the Norwegian press, posts social media and public intelligence reports. I also include data gathered from conversations with social workers and other individuals who have current or former connections with individuals belonging to the radical Muslim community in Oslo and the surrounding areas. Over several months, I gathered information from posts on social media (including Facebook, Twitter and YouTube) by a number of Norwegian Muslims who either employ violence-promoting rhetoric, or who have engaged in armed struggle in Syria. Through analysing their statements, I hoped to gain a better understanding of their motivations and ideological positions.

\section{Participants}

Most of the informants in this study, including three interviewees, are members of the militant Salafi-inspired group Profetens Ummah ("The Ummah of the Prophet"). These young men are either immigrants or were born in Norway. Some were raised as Muslims, while others converted to Islam later in life (Akerhaug, 2013; Lia 2013). Profetens Ummah has connections with other Islamist groups outside Norway, including the controversial Islam4UK and al-Muhajiroun, both banned in the UK under various pieces of anti-terrorist legislation (BBC, 2012). Some of my interviewees have confirmed that the founders of alMuhajiroun, Anjem Choudary and Omar Bakri, have been mentoring members of Profetens Ummah and giving lectures via Skype. 
Throughout recent years, Profetens Ummah has gained widespread public attention in Norway for its controversial and sometimes hate-filled statements - more recently for honouring Islamic State (IS) in a 45-minute video interview in the Norwegian media (Skjærli et al., 2014). In line with militant Salafist rhetoric, and with parallels to the ideologies of al-Qaida and IS, members of the group promote an anti-democratic, antimodern and violent ideology, claiming that they represent the most authentic version of Islam. Violent jihad in defence of Islam is considered a duty to God, and since the beginning of the civil war in Syria in 2011, several individuals with links to Profetens Ummah have travelled to Syria and Iraq to fight alongside militant groups (Akerhaug, 2013; Lia and Nesser, 2014; Skjærli 2014). Consequently, for the last few years the group has been at the centre of debates in the Norwegian media concerning political expression and national security.

In addition to the members of Profetens Ummah, I was able to make contact with five Norwegian foreign fighters, who at the time of being interviewed had returned from Syria. The dramatic increase in the number of Norwegian foreign fighters travelling to Syria started in 2012. According to several sources, at least 80 Norwegian Muslims have travelled to Syria and Iraq, many of whom have participated in armed struggle (Dagens Næringsliv, 2015; PST, 2015; PST, 2016). Information about Norwegian Muslim foreign fighters is still quite limited, which makes it difficult to generalise about Norwegian foreign fighters as a group. What we do know from extensive media coverage, social media and public reports by the authorities, is that the Norwegian contingent of foreign fighters mainly consists of young men from Muslim families, although a significant number are converts (Aardal et al., 2014). According to an estimate provided by the Norwegian Police Security Service (PST), the majority of Norwegian foreign fighters have a "low level of education and weak relations to the labour market" (PST, 2015). Other estimates made by journalists suggest that 33 per cent have dropped out of high school and 31 per cent have a criminal record (Aardal et al., 2014).

It is important to note, however, that these informants are not necessarily linked to Profetens Ummah. Nor should they be associated with the more extreme statements advocated by some of Profetens Ummah's members. As already mentioned, there are many nuances within militant Salafist ideology with regard to both religion and politics, including when and how militant jihad should be applied. Since the outbreak of the Syrian conflict, and since the first foreign fighters started joining the conflict in 2012, individuals' justifications have varied (Hegghammer, 2014). The most commonly claimed motivation among my informants, however, seemed to be a desire to help Syria's Sunni Muslims, along with a strong desire to fulfil the religious duty to participate in jihad against the enemies of Islam.

\section{Ethical concerns and limitations}

The study of radicalisation poses many methodological challenges and ethical concerns. Throughout this project I have been dealing with sensitive information - especially with regards to informants who have been fighting in Syria. Obviously, these informants feel under pressure from the Norwegian authorities, as several Norwegian foreign fighters have been arrested and charged with terror offences upon their return (NRK, 2014). Consequently, the informants were very sceptical about my intentions and my role as a researcher. After some time, however, they agreed to respond anonymously via email. A youth worker, who has known them from years of social work, helped me collect the answers. 
Moreover, there are obvious challenges involved in conducting interviews via e-mail. As I was not able to meet the informants in person, it was difficult to evaluate the credibility of their answers, details about their ideological positions, or tell how far these individuals had come in the radicalisation process. On the other hand, I believe the e-mail interviews allowed the informants to be more open about their frustrations and grievances, as the interviews were completely anonymous.

Finally, the secretive and closed nature of Islamist groups and organisations poses a great methodological challenge. Consequently, my data relates to a relatively small number of people, who can scarcely be described as a probability sample. Nevertheless, I believe my data undoubtedly provides some interesting, first-hand insights into the motivations of some militant Salafists in Norway, in a field where empirical material is greatly underexplored by the academic community.

\section{Findings explored: Mapping out the root causes of radicalisation}

Based on the data collection I identified a range of factors that may explain why some individuals turn to militant Salafism. I have categorised these factors into two major themes: political factors and socio-psychological factors. In the following section I will examine these factors in further detail.

\section{Political factors}

\section{Double standards}

Several informants in the study expressed feelings of being treated according to a double standard by Norwegian society. A frequent example cited a lack of consistency in the use of the term "radicals" in public debate. For instance, individuals who travel to Syria to participate in armed struggle are labelled "radicals" and "extremists", among other things, by the media, politicians and the Norwegian Police Security Service (PST). In contrast, Norwegian citizens who travel to Israel to enlist in the Israeli army do not receive the same level of negative public attention. ${ }^{6}$ As a consequence, the informants felt discriminated against simply for being Muslim. This view was illustrated in a comment made by a Muslim activist in Oslo with links to the group Profetens Ummah:

Individuals and groups in Norway have travelled to Israel to enlist in the Israeli army without being imprisoned. This reflects a double standard. The laws must apply to everyone. It is precisely this discrimination that makes people radical. The Norwegian authorities create an enemy within society (Phone interview with Muslim activist, 08.07.14).

Additionally, some of the informants stated that Norwegian society operates with a double standard regarding freedom of speech. Some of the informants claimed that they are not allowed to express their opinions as openly as Norwegians. In an interview, Ubaydullah Hussain, the spokesman for, and one of the founders of, the Islamist group Profetens Ummah, expressed the following view:

We feel that freedom of expression is restricted when Muslims speak. Why can't we support Islamic State, al-Qaida and the Taliban, when Norwegians can support the

6 Since the 1980s, the Israeli organisation Sar-El has recruited several dozen Norwegians to the Israeli army (Eikje, 2014). More important, Norwegian (and Swedish and Danish) Jews have fought with the Israel Defence Forces (IDF) in Gaza (Veum, 2010). 
Israeli army, which the whole world community considers to be an occupying force? Why can't we talk about having Islamic laws, when Norwegians can join the Israeli army and support attacks over there? For us, freedom of expression is restricted. I do not support their way of democracy. (Interview with Ubaydullah Hussain, 15.07.14)

In Hussain's view, it is paradoxical that Norwegians may support what he and his likeminded fellows perceive as a terrorist state, while individuals who claim allegiance to Islamic State or al-Qaida may risk criminal prosecution. ${ }^{7}$

Equally, a number of the informants had experienced instances of offensive statements by non-Muslims being branded acceptable under the banner of freedom of speech. During a press conference with Profetens Ummah in 2012, Egzon Avdyli, another key member of the group who is now dead after fighting in Syria, complained about what he perceived as a double standard.

Why is it okay to attack our values? [You] speak in a condescending way about the Prophet Muhammad, peace be upon him, about the Sharia system, and about those who wear niqab or hijab. When some Muslims stand up against this, they are prosecuted, witch-hunted, or possibly imprisoned. Either the law should be equal for everyone, or you should include a new paragraph in the constitution stating that Muslims are not permitted to speak about this. (...) But don't you say that the freedom of speech applies to everyone! (Egzon Avdyli, Profetens Ummah 2012b)

Avdyli interpreted contemporary political debates about banning women from wearing the face-covering veil or niqab, as well as religious criticism using devices such as satire, as deliberate offences against his values and identity as a Muslim. On a similar note, Hussain did not understand the debates about Muslim women covering their heads in a society where bare waists are widely accepted. In the following comment he referred to what he perceived as an intrinsic contradiction:

This makes me question so-called "Western values". The UN Commission says that a woman is allowed to sell her body, but she is not allowed to cover her body. This should ring a bell in the Western society. (Interview with Ubaydullah Hussain, 15.07.14)

\section{Stigmatisation and polarisation in the public debate}

Feelings of being discriminated against on account of belonging to a certain group were reinforced by the frustration the informants felt about the way Muslims are presented in the media and in the public debate. Some of the informants stated emphatically that they felt stigmatised and "witch-hunted", and did not understand why they were labelled as "radicals" and "extremists" for either supporting, or taking part in, armed struggle in Syria. One of my interviewees, who had participated in armed combat in Syria, questioned why he, along with other foreign fighters, was being labelled a radical and a terrorist, when, according to his way of thinking, the Western allies were the true radicals:

7 The Norwegian criminal code (Straffeloven) makes it a criminal offence to form, participate in, recruit or provide either economic or material support to a terrorist organisation. In March 2015, three individuals were tried, and later convicted, under this legislation for supporting and fighting alongside The Islamic State (Brekke, 2015; Haram and Jørstad, 2015). 
We say that NATO along with the United States is the terrorist! We did not kill any of you, but you have killed many of us. Therefore, it is strange that we are labelled in that way. (Syria-jihadist A, e-mail interview 30.07.14)

These feelings of stigmatisation and of being "witch-hunted" encourage a perception of the Western media as biased and anti-Islamic. The level of mistrust felt towards the Norwegian authorities and Western media is revealed in the following comment made by the spokesperson for Profetens Ummah:

It should be noted that we do not trust the Western media. We do not trust the statements made by the police, the PST, and the government. The reason is that I have personally experienced their dishonesty and betrayal. Another thing is that we have nothing in common. How then could we trust them? I'd rather trust a Muslim I don't know, than trust a non-Muslim. This is because we have one thing in common: We are Muslims and we believe in Allah. You and I, for example, we have nothing in common (Interview with Ubaydullah Hussain 15.07.14).

\section{Foreign policies}

The feelings of mistrust and loathing towards the Norwegian authorities are strengthened by the view that the West is waging an ideological and military campaign against Islam. My findings reveal that a majority of the informants had concerns about Western foreign policies, claiming that the West is partly responsible for under-development in the Muslim world. One informant, who had been fighting in Syria, summarises this view:

There is a situation in the world where the West is attacking Muslim countries in order to keep us down. We are accused of being terrorists and dangerous. At the same time the West has secured its wealth by exploiting us. We got the dictators. You got the oil, the wealth and the peace. We have to work against this system! (Syria-jihadist $B$, e-mail interview 30.07.14)

Similarly, one of the informants explicitly cited Western foreign policies as a source of radicalisation. In a video posted online, a member of Profetens Ummah addressed the Norwegian government directly, demanding reconsideration of its foreign policies:

I'm not the reason for what you call radicalisation of Muslim youth. It is your responsibility to admit that your domestic and foreign policy [including] your participation in the crusade in our beloved Afghanistan and in other Muslim countries, your support for Israel and America, your bad treatment of Muslims, and the persecution of them in their countries and on the outside, are the main reasons for what you call radicalisation of Muslims. In reality you are the ones who are the extremists and the radicals. So don't point your finger at me, but take a look at yourselves (Moyheldeen Mohammad, 2012).

Among the informants there was an understanding that Norway is participating in the war against Islam through its membership of NATO and alliance with the U.S. During a demonstration in 2012, arranged by Profetens Ummah to protest against the Norwegian involvement in Afghanistan, this view was clearly conveyed. Arfan Bhatti, a well-known Norwegian radical, held that: "Norway is allied with forces of kuffar, such as Americans, 
British and NATO, in order to attack Muslims and Muslim countries" (Profetens Ummah 2012c). ${ }^{8}$

Moreover, some informants were especially incensed at the role Norway plays internationally: on the one hand portraying itself as a diplomatic state, but at the same time participating in military missions led by NATO and the U.S. in Muslim countries. A number of the informants mentioned Norway's arms industry as a source of anger and frustration:

Norway portrays itself as a nation of peace. But it is quite the contrary. They have participated in Libya, Iraq and Afghanistan. Not to mention the arms industry that Norway runs, which we don't hear much about. Norway earns billions of dollars on the sale of weapons, ammunition and bomb equipment to the U.S. and France, among others (...). At the same time, Norway officially condemns the [American] drone attacks in north Pakistan and Yemen. (...) But the reality is that Norway sells equipment to these drones. Norway is therefore involved in these attacks, although the government says they are against it. (Interview with Ubaydullah Hussain, 15.07.14)

Another of my interviewees expressed a similar concern:

Norwegians only understand their own perspective of the world, which is "we are the best with our democracy." Norwegians only see Spain when they go abroad. They don't see Gaza, Afghanistan, Somalia or Iraq. They don't see their evil role. We should pity Norwegians, really. (Syria-jihadist C, e-mail interview 30.7.14)

Subsequently, feelings of being alienated and stigmatised in Norway spur connections with the suffering of Muslims across the world, including key conflicts in Chechnya, Iraq and Palestine. The indiscriminate use of force, large-scale Muslim civilian casualties and suffering strengthen the impression that the West has no empathy with the many victims in Muslim countries. Some of my informants expressed that they feel undervalued for being Muslims:

On September 11, there were 2,900 people who lost their lives. Compared to that how many lives have been lost in Afghanistan? We're talking about hundreds of thousands in Iraq and Afghanistan. Not to mention how many people who have lost their homes, who have been displaced, and have lost their basic means for living due to the occupation of Iraq and Afghanistan. (...) In the West, it seems that Muslim blood is less worth than non-Muslim blood (Interview with Ubaydullah Hussain, 15.04.17)

\section{Socio-psychological factors}

So far my findings have suggested a range of political, or perhaps more accurately ideological factors, that may trigger a radicalisation process. Reflecting the findings from my internet research and interviews with members of Profetens Ummah, some of the Norwegian foreign fighters expressed both political and religious concerns. When asking about their motivations for going to Syria, four explained that they were motivated by a religious call, saying, for example, "It is a Muslim's duty to defend the weak when they are attacked" and "It is Sunnah to do jihad against the oppressors, whoever they may be".

8 The Arabic word kuffar is plural for kafir, usually translated as 'infidels' or 'apostates' (Egerton, 2011). 
Likewise, some of the informants emphasised the aggressive role of the West towards the Muslim world, and their religious obligation to respond with force.

In contrast to my internet research and interviews with members of Profetens Ummah, however, my e-mail interviews with Norwegian jihadists revealed a somewhat different side of the story. Interestingly, some of the informants cited a range of socio-psychological factors, such as poverty, underperformance at school, a sense of not belonging, and feelings of alienation in Norwegian society. These factors will be examined in more detail in the following section.

\section{Socio-economic deprivation and alienation}

Two informants expressed feelings of alienation, claiming that Norwegian society did not fully accept people who were not ethnic Norwegian. Their e-mails contained statements such as "Norway doesn't like us" and "You will get nowhere if you are not Norwegian". When asked about his motivation for going to Syria, one of the informants wrote:

Many people who travel to Syria feel that they don't belong anywhere - with the exception of a few. Many of us are unemployed. We cannot get a job no matter how many we apply for. Norway doesn't like us. Instead, we can make ourselves useful elsewhere: to God. We need do this in order for you to understand that Muslims cannot be killed without consequences. (Syria-jihadist A, e-mail interview 30.07.14)

Besides feelings of being alienated and detached from Norwegian society, I discovered in the e-mail interviews that two informants referred to a variety of socio-economic factors, such as underperformance at school, unemployment and poverty. For example, one informant reflected on his low self-image and low self-esteem, describing himself as a "loser":

In Norway you get nowhere if you are not Norwegian. Our parents worked hard to get to Norway. We did not make use of that opportunity. We did not pay attention at school because it was too difficult for us, and we became losers. Our parents are poor, and we became even bigger losers. (Syria-jihadist B, e-mail interview 30.07.14)

However, socio-economic factors such as unemployment, lack of opportunity, poor language skills, low levels of integration, and underperformance at school do not appear to provide a full explanation of why some Norwegian Muslims become attracted to violent interpretations of Islam. For instance, some of the other informants in my sample were born and raised in Norway. They spoke perfect Norwegian, had jobs and were apparently well-integrated. This indicates a second factor that should be included in the analysis, namely a search for identity.

\section{The search for identity}

Some individuals may have personal qualities that drive them to work hard to succeed, although at the same time they struggle to find meaning and a sense of belonging. As the e-mail interviews revealed, some of the informants did not feel completely accepted and integrated into Norwegian society. The struggle to find a sense of belonging was further illustrated by the self-styled "loser", who continued:

...When you are a loser you want to hide it. We stole mobile phones and fashionable clothes in order to be like the others, and to have the same things as them. But we were not like the others. We only had friends like ourselves. But a way out of this vicious cycle is to dedicate oneself to God and work for his cause. We know how it is. Finally, God is the only one to answer to. (Syria-jihadist B, e-mail interview 30.07.14) 
Yousef Assidiq, an ethnic Norwegian convert and a former "radical", emphasises that extremist groups offer an obvious refuge for young individuals in a vulnerable position. In 2010, before the official founding of Profetens Ummah, Assidiq became involved with some of its future members. He joined several demonstrations and activities, before suddenly realising that their ideology was too extreme for him. As a result, he decided to leave the group. In a phone conversation with him, he explained why he initially became attracted to the violent interpretation of Islam advocated by Profetens Ummah. In line with the Norwegian jihadists, he refers to the need for belonging:

There are many mechanisms leading to radicalisation. One may feel discriminated against, or one may feel left out. This puts you in a vulnerable position and makes it easier for the extremists to draw you in. Personally, I know how it feels to be discriminated against, and to feel left out. When I converted to Islam I felt very alone. My parents, friends and neighbours did not support the choice that I had made. As a consequence, I got in touch with more radical people. To me, these people offered the most obvious protection (Phone interview with Yousef Assidiq, 06.06.14).

\section{Discussion: What militant Salafism offers}

The findings arising from the data I collected offer some answers as to why some Norwegian Muslims become attracted to militant Salafism. I have identified several factors that may trigger a radicalisation process. These factors relate to political grievances, real or perceived discrimination, feelings of alienation and stigmatisation in the public debate, a sense of not belonging, and socio-economic deprivation. Based on an analysis of the individual statements and claims, I found that all the informants expressed feelings of resentment or injustice at having been unfairly treated in some way, or to paraphrase Wiktorowicz (2005), they had all experienced some sort of crisis. A real or perceived experience of injustice, derived from factors such as Western foreign policies towards the Muslim world or feelings of being excluded from the Norwegian society, may trigger what Wiktorowicz defines as a cognitive opening. This may lead individuals to start questioning previously held beliefs and become receptive to new ideas. Militant Salafist ideology articulates these frustrations and grievances, and provides an alternative worldview for these individuals to identify with.

In the following section, I further discuss the meaning and significance of my findings in relation to existing literature on radicalisation. I will argue in line with the theories of Oliver Roy (2004) and Quintan Wiktorowicz (2005) that there are three main dimensions that draw some Norwegian Muslims towards militant Salafism, namely (1) a search for justice; (2) a search for community; and (3) a search for meaning. It is important to emphasise that these dimensions are not easily separated from each other. Some individuals expressed a combination of political, religious and social concerns.

\section{(1) The political dimension: the search for justice}

In my interviews and throughout my internet research, I noticed the frustration the informants felt about Norwegian and Western foreign policies towards the Muslim world. Norway's arms industry, along with its participation in military missions led by the U.S. and NATO, may also contribute to the radicalisation of Muslims at home. Hence, in order to fully comprehend why young Norwegian Muslims become attracted to militant Salafism, we need to realize that Western foreign policies play a serious role in triggering radicalisation, and 
that the rhetoric of Western states has contributed to a political image of the West as being war with Islam.

According to Oliver Roy (2004), the suffering of Muslims in other parts of the world connects with local first-hand experiences of stigmatisation and exclusion in Norway. As a consequence, feelings of injustice and humiliation provoke a strong need for justice and dignity. Militant Salafism provides an alternative worldview for these justice-seeking individuals. As the objective of militant Salafism is to fight back at what its supporters perceive as an aggressive West, it may provide what Roy defines as a "just cause", through which dignity and justice can be retrieved. Such a determination to retrieve dignity and justice is illustrated by the following comment made by Egzon Avdyli, a member of Profetens Ummah:

There is no doubt. We will continue to work to reveal the cruelty committed by the West in Muslim countries, to work against the Israeli occupation of Palestine, to reveal the hypocrisy of the Norwegian politicians in this country, as well as to spread Islam in order to make Allah's laws apply everywhere (...). (Profetens Ummah, 2012b)

\section{(2) The social dimension: the search for community and a sense of belonging}

As we have observed from the data collection, some of the informants expressed feelings of alienation and a sense of not belonging. As a consequence of feeling unfairly treated, individuals may start searching for a community where they can share their frustrations. Wiktorowicz (2005) discusses the role of Islamist groups and movements in articulating individuals' frustrations and providing a collective identity. Communities do not necessarily need to be physical; particularly nowadays they may be virtual, with internet forums and online chatrooms playing an important role in shaping specific political and religious perceptions and creating a sense of community. Roy (2004) maintains that the sense of community is grounded in the feeling of solidarity and affiliation with the Islamic ummah. Through devotion to a global community of true believers, individuals come to identify and conceptualise themselves as part of a collective. In a video posted online, a member of Profetens Ummah expresses his sense of pride and superiority in belonging to the ummah:

You should know that the Islamic ummah is an ummah of victory and glory. It is an ummah of jihad and martyrdom that will never give in or surrender to your evilness, injustice, and deceit (Moyheldeen Mohammad, 2012)

In my internet research and throughout the interviews, I found that the informants identified themselves primarily in religious terms, using language such as "Us Muslims" against "You infidels". As Ubaydullah Hussain put it quite clearly: "There are two camps in the world. Muslims and non-Muslims." (Interview with Ubaydullah Hussain, 15.07.14.) The dichotomous worldview advocated by the informants illustrates what Wiktorowicz (2005) explains as the social production of meaning. The strong division between "Us" and "The Others" reinforces a sentiment of brotherhood and collective identification. This offers an alternative to what they perceive as a hostile and exclusive Norwegian society. In a Norwegian newspaper, the former "radical" Yousef Assidiq explains why this particular way of thinking appealed to him:

I met people who understood me. [The radicals] draw upon familiar hostile images of a war between the West and Islam, and [the idea] that Muslims will never be accepted in Europe. This is exactly how I felt after I had converted [from Christianity to Islam] - I felt like everyone was against me (Byrkjedal et al., 2014). 
In summary, militant Salafism can provide a collective outlet for complex emotions of anger and frustration, and may offer solutions to feelings of alienation, lived or perceived stigmatisation and a sense of not belonging. At the same time, brotherhood and solidarity with the Islamic ummah provides a sense of belonging.

\section{(3) The religious dimension: the search for meaning}

Lastly, militant Salafism may offer stability in a chaotic world by providing clear guidelines for how to respond to an unpleasant situation, as well as directing social behaviour. When experiencing an identity crisis due to real or perceived stigmatisation, alienation or exclusion, individuals may start questioning what it means to be a Muslim living in a nonMuslim country. Militant Salafism may provide solutions to its followers' concerns by offering alternative explanations that help them to make sense of their reality. As we saw in the previous section, one of the interviewees explained that his way out of a vicious cycle of crime and lack of opportunity was to devote himself to religion.

In the literature on radicalisation, commentators have argued that young Muslims become attracted to militant Salafism because it provides a set of identities and meanings, often based on the "true" and most authentic interpretation of Islam (Wiktorowicz, 2005). In my interviews with two key members of Profetens Ummah, both men emphasised that they supported the ideology of Osama bin Laden and Al-Qaida because it somehow represented the most authentic version of Islam:

The ideology of Al-Qaida and Osama bin Laden derives from the Quran and the teachings of the Prophet. (...) A person who differs from these beliefs differs from what the Prophet and the Quran taught him. Every Muslim is obliged to work for the liberation of an occupied territory. If they don't, they are all sinners. (Interview with member of Profetens Ummah, 15.07.14)

Based on a strict interpretation of Islam which directs individuals' behaviour, militant Salafism provides clear guidelines as to what is and what is not permitted. Accordingly, it may offer individuals a sense of stability and certainty, along with answers to pressing issues.

\section{Conclusion}

By drawing upon existing literature on violent radicalisation, this article has aimed to conduct an empirical exploration of the causes of violent radicalisation in Norway in order to answer the research question "Why do some Norwegian Muslims become attracted to militant Salafism?"

Based on interviews and extensive internet research, I have identified a range of complaints and grievances that may prompt a radicalisation process. The grievances involve factors that are both political and ideological (Western foreign policies; polarisation in public debate), socio-psychological (alienation and a sense of not belonging) and socio-economic (discrimination in the labour market and underperformance at school). What is important to note, however, is the distinction between perceived and real injustices. Obviously, individual allegations and grievances do not necessarily correspond to real situations - although they may well do so. An assessment of the legitimacy of the informants' arguments has been beyond the scope of this article. Rather, the objective has been to try to understand what drives these individuals into extreme positions. What I find is that all the informants share 
feelings of strong resentment or injustice due to experiences that they believe to be wrong or unfair.

Accordingly, I argue, in line with Oliver Roy (2004) and Quintan Wiktorowicz (2005) that militant Salafism respond to individuals' grievances by offering an alternative worldview that provides a sense of justice, meaning and community based on shared religion and ideology. Firstly, militant Salafism articulates individuals' feelings of anger and frustration. As the objective of militant Salafism is to fight back at what its supporters perceive as an aggressive West, it provides what Roy (2004) defines as a "just cause", through which dignity and justice can be retrieved. Secondly, militant Salafism offers community. As an alternative to feelings of alienation, stigmatisation and not belonging, the collective sentiment of brotherhood and solidarity offered by the Islamic ummah provides a sense of belonging. Finally, by offering clear guidelines that direct individual behaviour, militant Salafism provides meaning, certainty and stability in a chaotic world.

Interestingly, the grievances and allegations articulated by the Norwegian militant Salafists do not represent a Norwegian-specific narrative, but rather reflect what is found in the broader literature on the radicalisation of young Muslims living in Europe. For further research, it would be interesting to investigate if there is anything specific about the Norwegian context that make militant Salafism appealing to young Muslims living there. For the purposes of conducting such research, it would be useful to collect extensive quantitative data on factors such as performance at school and representation in the labour market among Norway's Muslim minority. Some journalists and representatives of the Norwegian authorities have already attempted to gather such information about Norwegian foreign fighters. So far the evidence suggests that these individuals are generally marginalised, both socially and economically (PST, 2015; Aardal et.al, 2014). With regard to political factors, many scholars have referred to the role of foreign policy as a source of radicalisation, but few have offered comprehensive analyses of its role in relation to domestic radicalisation.

The strength of adopting a root-cause-based approach to the study of radicalisation is that it addresses the conditions and circumstances in which violence and radical ideas may grow and take root (Bjørgo, 2005). In order to understand the appeal of militant Salafism, it is important to gain an insight into individuals' own motivations and understandings of their situations. However, this is not the end of the story. The main problem with the root-causebased approach is perhaps that it does not necessarily explain what triggers individual involvement. Structural conditions such as economic and political circumstances affect thousands of people. Why then does only a small minority of the population become attracted to militant Salafism? In order to answer this question, it may be necessary to take a closer look at the various mechanisms of recruitment and mobilisation that channel radical ideas into action. Such mechanisms of mobilisation could be studied by looking at the internet as a ground of recruitment, the influence of leaders and imams, important meeting places such as mosques or youth clubs, and - perhaps most importantly - the role of groups and social networks.

Nevertheless, I believe that in order to fully comprehend why some individuals come to accept the use of violence in the name of Islam, it is essential to include in the analysis the perspective of the individual, the narrative of their ideology, and their relationship with society. The latter factor is especially important, since the growth of violent and extremist ideas does not occur in a vacuum, but rather in response and in relation to an individual's surroundings. 


\section{References}

Aardal, E., C. Svendsen, V. Krumins, P.Haza and G. Imrie (2014). Stor kartlegging: Dette er dei norske fremandkrigarane. NRK, November 27, http://www.nrk.no/norge/desse-vart-framandkrigarar-1.12061691.

Akerhaug, L. (2013). Norsk Jihad: Muslimske ekstremister blant oss. Oslo: Kagge Forlag AS.

BBC (2012). Government to ban Islam4UK under terror laws. BBC online news, January 12, http://news.bbc.co.uk/2/hi/uk_news/8453560.stm (29.08.14)

Bjørgo, T. (ed.) (2005). Root Causes of Terrorism: Myths, Reality, and Ways Forward. London and New York: Routledge. http://dx.doi.org/10.4324/9780203337653

Brekke, A. (2015). Ber om fem års fengsel for IS-tiltalte. NRK. March 17, http://www.nrk.no/norge/ber-om-fem-ars-fengsel-for-is-tiltalte-1.12264801 (08.06.2015)

Byrkjedal, M., I. Hvidsten, O. Mjaaland and B. Tommelstad (2014). Slik rekrutteres Syriakrigerne. VG. July 27, http://www.vg.no/nyheter/innenriks/terrorisme/slik-rekrutteres... (29.08.14)

Coolsaet, R. (ed.) (2011). Jihadi Terrorism and the Radicalisation Challenge:

European and American Experience. (2nd ed.) Farnham: Ashgate.

Dagens Næringsliv (2015). PST tror antallet fremmedkrigere er høyere enn kjent. DN. March 23, http://www.dn.no/nyheter/politikkSamfunn/2015/03/23/2042/Politiets... (03.06.15)

Dalgaard-Nielsen, A. (2010). Violent Radicalization in Europe: What We Know and What We Do Not Know. Studies in Conflict \& Terrorism, 33(9), 797-814. http://dx.doi.org/10.1080/1057610X.2010.501423

Egerton, F. (2011). Jihad in the West: The Rise of Militant Salafism. Cambridge: Cambridge University Press. http://dx.doi.org/10.1017/CBO9780511757594

Eikje, O. (2014). 50 nordmenn rekruttert til Israels hær. Dagen, March 10, http://www.dagen.no/Samfunn/50_nordmenn_rekruttert til... (08.08.2014)

Emerson, M. (ed.) (2009). Ethno-Religious Conflict in Europe: Typologies of Radicalisation in Europe's Muslim Communities. Brussels: Centre for European Policy Studies.

Githens-Mazer, J. and R. Lambert (2010). Why Conventional Wisdom on Radicalization fails: The Persistence of a Failed Discourse. International Affairs, 86 (4), 889-901. http://dx.doi.org/10.1111/j.1468-2346.2010.00918.x

Haram, I. and R. Jørstad (2015). Norske IS-krigere terrordømt. NRK. May 8, http://www.nrk.no/norge/norske-is-krigere-terrordomt.. (15.02.16)

Hegghammer, T. (2013a). Number of foreign fighters from Europe in Syria is historically unprecedented. Who should be worried?. Washington Post, November 27,http://www.washingtonpost.com/blogs/monkey-cage... (19.08.2014)

Hegghammer, T. (2013b). Should I stay or Should I Go? Explaining Variation in Western Jihadists Choice between Domestic and Foreign Fighting. American Political Science Review, 107 (1), 1-15. 
Hegghammer, T. (2014). Norske fremmedkrigere i går og i dag. Norsk statsvitenskapelig tidsskrift, 30(4), 277-288.

Hussain, Ubaydullah (2014): Ingen kan stoppe Jihad!. Chronicle posted on Facebook. June 23, www.facebook.com (23.06.14)

Korteweg, R., S. Gohel, F. Heisbourg, M. Ranstorp and R. D. Wijk (2010). Background contributing factors to terrorism: Radicalisation and recruitment. In M. Ranstorp (ed.) Understanding Violent Radicalisation: Terrorist and Jihadist Movements in Europe. New York: Routledge. pp: 21-49.

Kundnani, A. (2014). The Muslims Are Coming! Islamophobia, Extremism, and the Domestic War on Terror. London and New York: Verso Books.

Lia, B. (2013). Profetens Ummah og sosiale medier. In I. M. Sunde (ed.) Forebygging av radikalisering og voldelig ekstremisme pa internett. PHS Forskningsrapport No 2013:1. pp. 105-112. Oslo: Politihøyskolen.

Lia, B. and P. Nesser (2014). Norske muslimske fremmedkrigere. Nytt norsk tidsskrift, 31(4), 399-416.

McCauley, C. and S. Moskalenko (2008). Mechanisms of Political Radicalization: Pathways Toward Terrorism. Terrorism and Political Violence, 20(3), 415-433. http://dx.doi.org/10.1080/09546550802073367

Maher, S. (2007). Road to Jihad: Almost impossible to regulate, the web is a gift for a new generation of young extremists. Sage Journals, 36(4), 144-147. http://dx.doi.org/10.1080/03064220701740590

Mohammad, Mohyeldeen (2012). Mohyeldeen Mohammad - Beskjed fra Syria. March 12, https://www.youtube.com/watch?v=YYsf89tF2LY $(21.08 .14)^{9}$

Musawi, M. A. (2010). Cheering for Osama: How Jihadists use Internet Discussion Forums. London: Quilliam Foundation.

Nesser, P. (2010). Joining jihadi terrorist cells in Europe: Exploring motivational Aspects of recruitment and radicalisation'. In M. Ranstorp (ed.), Understanding Violent Radicalisation: Terrorist and Jihadist Movements in Europe (pp. 87-114). New York: Routledge.

NRK (2014). Tre personer arrestert for terrorplaner. NRK. May 27, http://www.nrk.no/norge/tre-personer-arrestert-for-terror-1.11742131 $(29.08 .14)^{10}$

Neumann, P. R. and B. Rogers (2007). Recruitment and Mobilisation for the Islamist Militant Movement in Europe. London: King's College London.

Profetens Ummah (2012a). Demonstrasjon utenfor den amerikanske ambassaden i Oslo 29.09.12.

Oct 16, https://www.youtube.com/watch?v=mvMutwXVxWs (21.08.14)

Profetens Ummah (2012b). Pressekonferanse Profetens Ummah. Nov 12, https://www.youtube.com/watch?v=OfJDHWVQGoE (21.08.14)

Profetens Ummah (2012c). Demonstrasjon mot norsk deltagelse i Afghanistan. Sept 18, https://www.youtube.com/watch?v=SesfOD6rjws (21.08.14)

9 English version available from: http://www.liveleak.com/view?i=1c3 1353236607 10 English version available from:

http://www.dailystar.com.Ib/News/International/2014/May-27/257832-norway-three-arrested-for... 
PST (2014). Norske fremmedkrigere i Syria. Politiets sikkerhetstjeneste, June 18, http://www.pst.no/media/utgivelser/norske-fremmedkrigere-i-syria/ (21.08.14)

PST (2015). Apen trusselvurdering 2015 (Annual threat evaluation). Politiets sikkerhetstjeneste, http://www.pst.no/media/75480/PSTs_tv2015.pdf (03.06.15)

PST (2016). Trusselvurdering 2016 (Annual threat evalutation). Politiets sikkerhetstjenester, http://www.pst.no/media/81096/PST Brosjyre Trussel NORSK.pdf (15.02.16)

Ranstorp, M. (2010): Introduction. In M. Ranstorp (ed.) Understanding Violent Radicalisation: Terrorist and Jihadist Movements in Europe. New York: Routledge.

Roy, O. (2004). Globalized Islam: The search for a New Ummah. London: Hurst and Company Ltd.

Roy, O. (2008). Al Qaida in the West as a Youth Movement: The Power of a Narrative. CEPS Policy Brief. No. 168.

Sageman, M. (2004). Understanding Terror Networks. Philadelphia: University of Pennsylvania Press.

Sageman, M. (2008). Leaderless Jihad: Terror Networks in the Twenty-First Century. Philadelphia: University of Pennsylvania Press.

Skjærli, B., M. Hopperstad, J. Tjersland, S. Ensrud, N. Kleivan and H. Henden (2014). Støtter IS-halshugging (video interview). VGTV, Aug 18, http://www.vg.no/nyheter/innenriks/islam-debatten/stoetter-is-halshugging... (07.01.2015)

Slootman, M. and J. Tillie (2006). Processes of Radicalisation: Why some Amsterdam Muslims become radicals. Amsterdam: University of Amsterdam.

Taylor, M. and J. Horgan (2006). A Conceptual Framework for Addressing Psychological Process in the Development of the Terrorist. Terrorism and Political Violence. Volume 18. pp. 585-601. http://dx.doi.org/10.1080/09546550600897413

Veum, E. (2010). Norske soldater i strid for Israel. NRK. March 15, http://www.nrk.no/norge/norske-soldater-i-strid-for-israel-1.7039428 (23.02.2016)

Wiktorowicz, Q. (2005). Radical Islam rising: Muslim Extremism in the West. Oxford: Rowman \& Littlefield. 